\title{
Peningkatan Hasil Belajar Siswa Dalam Pembelajaran PKN Dengan Model Kooperatif Tipe TPS Di Kelas IV SD
}

\author{
Kukuh Vandriani \\ Sekolah Dasar 10 Bandar Buat, Kota Padang \\ * e-mail:kvandriani@gmail.com
}

\begin{abstract}
This research is motivated by the less varied learning of Civics methods and learning model of Civics used, less digging knowledge of students who ask questions related to teaching materials that are taught, not yet forming study groups in pairs, have not created group discussion. The purpose of this study is to describe the planning, implementation and learning outcomes of students in learning Civics model with cooperative type TPS. The type of this research is Action Research The classroom approach used is qualitative and quantitative. Subjects in the study were teachers and students of grade IV. The results showed improvement in student learning outcomes, namely cycle I was $67 \%$ and in cycle II $90 \%$.
\end{abstract}

Keywords: model with cooperative type TPS



\section{PENDAHULUAN}

Pendidikan kewarganegaraan $(\mathrm{PKn})$ merupakan salah satu mata pelajaran yang digunakan sebagai wahana untuk mengembangkan dan melestarikan nilai luhur dan moral yang berakar pada budaya bangsa Indonesia. Hal ini sesuai dengan yang dijelaskan oleh Aziz, dkk (2002: 1.1) menyebutkan "Pendidikan pancasila dan kewarganegaraan atau PKn dapat diartikan sebagai program pendidikan yang bertolak dan memusatkan perhatian pada konsep, nilai, moral, norma dan perilaku sesuai pancasila dan UUD 1945 serta hak dan kewajiban termasuk bela negara".

PKn memiliki tujuan di Sekolah Dasar untuk membentuk watak atau karakteristik warga Negara yang baik dan diharapkan dapat mempersiapkan siswa menjadi warga Negara yang memiliki komitmen kuat dan konsisten untuk mempertahankan Negara Kesatuan Republik Indonesia

Berdasarkan hasil observasi yang peneliti lakukan di kelas IV SDN 10 Bandar Buat Kota Padang pada tanggal 7 oktober 2015 jam 2.00 wib di kelas IV terlihat permasalahan dari aspek guru dalam pembelajaran PKndiantaranya yaitu: (1)Guru kurang bervariasinya metode dan model pembelajaran Pkn yang digunakan (2) Guru kurang menggali pengetahuan siswa dengan mengajukan pertanyaan terkait dengan materi pelajaran yang akan diajarkan, (3) Guru belum membentuk kelompok belajar secara berpasangan, (4) Guru belum menciptakan diskusi 


\section{Kukuh Vandriani}

kelompok, sehingga siswa belum saling berbagi pengetahuan diantara mereka dalam memahami materi.

Permasalahan di atas berdampak pula terhadap siswa, diantaranya yaitu: (1) Siswa lebih banyak diam dan mendengarkan materi yang disampaikan, (2) Siswa terlihat belajar sendirisendiri tanpa ada interaksi yang berarti dengan teman lainnya, (3) Tidak adanya kerjasama yang dilakukan siswa satu dengan siswa lainnya mengenai pembelajaran yang sedang dipelajari.

Dari permasalahan yang telah dikemukakan, untuk dapat meningkatkan hasil belajar siswa dalam pembelajaran Untuk dapat meningkatkan hasil belajar siswa dalam pembelajaran PKn guru dapat menggunakakan model pembelajaran yang sesuai dengan materi yang diajarkan, salah satu model pembelajaran yang cocok digunakan dalam pembelajaran PKn adalah model pembelajaran kooperatif. Model pembelajaran kooperatif menutur Slavin (dalam, Nurasma 2008:2) "dalam belajar kooperatif siswa belajar bersama, saling menyambung pemikiran dan bertanggung jawab terhadap pencapaian hasil belajar secara individu maupun kelompok".Selain itu pembelajaran kooperatif juga dapat menghilangkan prasangka buruk terhadap teman sebaya, menimbulkan motifasi siswa dan tidak bersifat kompetitif.

Selanjutnya, Salah satu tipe pembelajaran kooperatif adalah tipe TPS. dikembangkan oleh Frank Lyman,dkk dari Universitas Maryland pada tahun 1985 (dalam miftahul 2011: 81),’Model pembelajaran ini merupakan salah satu cara yang afektif untuk membuat variasi suasana pola diskusi berpasangan yang dilanjutkan dengan diskusi pleno sehingga memberi siswa kesempatan untuk bekerja sendiri serta bekerja sama dengan orang lain”.

Berdasarkan uraian di atas, secara khusus penelitian ini ingin mendeskripsikan:

Rencana pelaksanaan pembelajaran untuk peningkatan hasil belajar siswa dalam pembelajaran PKn dengan menggunakan Model Koopereatif Tipe TPS di kelas IV SD Negeri 10 Bandar Buat Kota Padang, (2) pelaksanaan pembelajaran untuk peningkatan hasil belajar siswa dalam pembelajaran PKn dengan Model Kooperatif Tipe TPS di kelas IV SD Negeri 10 Bandar Buat Kota Padang ,(3) peningkatan hasil belajar siswa dalam pembelajaran PKn dengan Model Kooperatif Tipe TPS di kelas IV SD Negeri 10 Bandar Buat Kota Padang.

\section{METODE PENELITIAN}

Jenis penelitian yang dilaksanakan adalah Penelitian Tindakan Kelas (PTK).PTK adalah penelitian yang dilakukan oleh orang terlibat didalamnya, serta bertujuan untuk melakukan perbaikan dalam berbagai aspek. Seperti yang dijelaskan oleh Hamzah(2011:40) "Penelitian Tindakan Kelas adalah penelitian yang dilakukan oleh guru di dalam kelasnya sendiri melalui refleksi diri, dengan tujuan untuk memperbaiki kinerjanya sebagai guru, sehingga proses pembelajaran dapat berjalan dengan baik, dan hasil belajar siswa meningkat"..Pendekatan yang digunakan dalam penelitian ini adalah pendekatan kualitatif dan kuantitatif.Pendekatan kualitatif 
digunakan karna metode penelitian yang bertujuan untuk mendapatkan pemahaman tentang kenyataan melalui proses berfikir induktif. Seperti yang dikemukakan oleh Bogdan(dalam Basrowi, 2008:21) menyatakan bahwa "Penelitian kualitatif adalah salah satu prosedur penelitian yang menghasilkan data deskriptif berupa ucapan atau tulisan dan perilaku orang-orang yang diamati".Sementara itu pendekatan kuantitatif menurut Nanang (2011:20) "Pendekatan kuantitatif penelitian dilakukan dengan mengumpul data berupa angka.Data yang berupa angka tersebut kemudian diolah dan dianalisis untuk mendapatkan suatu informasi ilmiah di balik angka-angka tersebut".

Penelitian dilaksanakan dilaksanakan di kelas IV SD Negeri 10 Bandar Buat Kota Padang yang terdaftar pada tahun ajaran 2015/2016 dengan jumlah siswa 18 orang yang terdiri dari 14 orang perempuan dan 4 orang laki-laki (Data SDN 10 Bandar Buat yang terdaftar pada semester II tahun ajaran 2015/2016). Penelitian ini dilaksanakan selama 6 (enam) bulan pada semester Januari-Juni tahun 2015/2016. Sumber data yang digunakan dalam penelitian ini adalah proses pembelajaran IPS dengan menggunakan model pembelajaran Kooperatif tipe TPS pada siswa kelas IV yang terdiri dari perencanaan, pelaksanaan, dan hasil belajar.

Data penelitian ini dikumpulkan dengan menggunakan hasil observasi dan hasil tes. Dalam penelitian ini, instrumen yang digunakan berupa lembar hasil observasi RPP, lembar hasil observasi dari aspek guru dan aspek siswa serta hasil tes. Data yang telah terkumpul dianalisis dengan tahapan: (1) Menelaah data yang telah terkumpul baik melalui observasi, dokumentasi, (2) Menyajikan data (3) Menyimpulkan hasil penelitian tindakan ini merupakan penyimpulan akhir penelitian.

\section{HASIL PENELITIAN DAN PEMBAHASAN}

\section{Hasil Penelitian}

\section{Siklus I}

\section{Perencanaan}

Perencanaan pembelajaran disusun dan dikembangkan berdasarkan Kurikulum Tingkat Satuan Pendidikan (KTSP) mata pelajaran PKn kelas IV semester II. Menyusun RPP yang meliputi: standar kompetensi, kompetensi dasar, indikator, menetapkan materi pembelajaran, menyusun kegiatan pembelajaran, menetapkan media, sumber belajar dan penilaian. Adapun standar kompetensi dalam penelitian ini adalah 3. Menunjukkan sikap terhadap globalisasi di lingkungannya.KD 4.1 Menyebutkan contoh sederhana pengaruh globalisasi di lingkungannya. Media yang digunakan yaitu Gambar warnet, telpone,pakaian.

Penilaian terhadap RPP dilaksanakan melalui lembar penilaian RPP dengan aspek penilaian yang terdiri dari: (a) kejelasan perumusan tujuan pembelajaran, (b) pemilihan materi ajar, (c) 
pengorganisasian materi ajar, (d) pemilihan sumber/media pembelajaran, (e) Kejelasan proses pembelajaran,(f) teknik pembelajaran, $(\mathrm{g})$ format Penilaian.

\section{Pelaksanaan}

Pelaksanaan pada siklus I penelitian ini disesuaikan dengan dengan langkah-langkah yang dikembangkan Menurut Trianto (2012 :81-82) (1) thinking ( berfikir ) guru mengajukan suatu pertanyaan atau masalah yang dikaitkan dengan pelajaran, dan meminta siswa menggunakan waktu beberapa menit untuk berfikir sendiri jawaban atau masalah,siswa membutuhkan penjelasan bahwa berbicara atau mengajarkan bukan bagian berfikir, (2) pairing ( berpasangan) selanjutnya guru meminta siswa untuk berpasangan dan mendiskusikan apa yang telah mereka peroleh,interaksi selama waktu yang disediakan dapat menyatukan jawaban jika suatu pertanyaan yang diajukan atau menyatukan gagasan apabila suatu masalah khusus yang diidentifikasi,secara normal guru member waktu tidak lebih dari 4-5 menit untuk berpasangan, (3) sharing(berbagi) pada langkah akhir ,guru meminta pasang-pasangan untuk berbagi dengan keseluruhan kelas yang telah mereka bicarakan ,hal ini Afektif untuk berkeliling ruangan dari pasangan ke pasangan dan melanjutkan sampai sekitar sebagian pasangan mendaptkan kesempatan untuk melaporkan..

\section{Pengamatan}

Kegiatan pengamatan dilakukan oleh observer untuk mengamati aktivitas guru dan aktivitas siswa selama pembelajaran berlangsung.Berdasarkan hasil pengamatan siklus I pertemuan I persentase aktivitas guru ialah $85 \%$ dan persentase aktivitas siswa adalah $85 \%$.

\section{Refleksi}

Berdasarkan hasil diskusi dengan observer pada tahap refleksi, kekurangan yang terjadi pada aspek guru dan siswa pada siklus I adalahkurangnya reverensi siswa tentang objek yang digemari dalam membuat kerangka tulisan dan menulis deskripsi.Serta siswa tergesa-gesa dalam merevisi tulisannya karena peneliti akan memberikan kesempatan bagi siswa yang tercepat dalam menyelesaikan tulisannya akan menjadi bintang kelas dan diizinkan untuk membacakan tulisannya didepan kelas sehingga tulisan siswa kurang bersih dan rapi, serta siswa kurang memperhatikan ejaan, huruf kapital, dan tanda baca yang benar. Berdasarkan refleksi yang dilakukan, maka pada siklus berikutnya peneliti akan menganti topik menjadi objek yang disukai siswa karena objek yang disukai lebih fleksibel dibandingkan dengan objek yang digemari. serta menambah reverensi siswa dalam menulis dengan cara memperbanyak variasi media, seperti media gambar, dan media contoh tulisan deskripsi menggunakan ejaan, huruf kapital tanda baca, dengan susunan paragraf yang bersih dan rapi. Dengan refleksi ini diharapkan pelaksanaan pembelajaran menulis deskripsi menggunakan pendekatan konstruktivisme dapat dilakukan dengan baik, sehingga siswa mengalami peningkatan dalam keterampilan menulis deskripsi.

\section{Siklus I}




\section{Perencanaan}

Untuk memperbaiki kekurangan yang ada pada siklus I maka dilakukan tindakan perbaikan pada siklus II.Penyusunan perencanaan tindakan Pembelajaran tematik terpadu berpedoman pada Kurikulum 2006 (KTSP)diwujudkan dalam bentuk RPP.RPP yang dilaksanakan memuat (1) identitas, (2) kompetensi inti, (3) kompetensi dasar dan indikator, (4) tujuan pembelajaran, (5) materi pembelajaran (6) model, pendekatan dan metode pembelajaran, (7) media dan sumber pembelajaran, (8) langkah kegiatan pembelajaran serta (9) Penilaian hasil belajar.

\section{Pelaksanaan}

Pelaksanaan pada siklus II penelitian ini disesuaikan dengan dengan langkah-langkah yang dikembangkan Menurut Trianto (2012 :81-82) (1) thinking ( berfikir ) guru mengajukan suatu pertanyaan atau masalah yang dikaitkan dengan pelajaran, dan meminta siswa menggunakan waktu beberapa menit untuk berfikir sendiri jawaban atau masalah,siswa membutuhkan penjelasan bahwa berbicara atau mengajarkan bukan bagian berfikir, (2) pairing ( berpasangan) selanjutnya guru meminta siswa untuk berpasangan dan mendiskusikan apa yang telah mereka peroleh,interaksi selama waktu yang disediakan dapat menyatukan jawaban jika suatu pertanyaan yang diajukan atau menyatukan gagasan apabila suatu masalah khusus yang diidentifikasi,secara normal guru member waktu tidak lebih dari 4-5 menit untuk berpasangan, (3) sharing(berbagi) pada langkah akhir ,guru meminta pasang-pasangan untuk berbagi dengan keseluruhan kelas yang telah mereka bicarakan ,hal ini Afektif untuk berkeliling ruangan dari pasangan ke pasangan dan melanjutkan sampai sekitar sebagian pasangan mendaptkan kesempatan untuk melaporkan..

\section{Pengamatan}

Kegiatan pengamatan dilakukan oleh observer untuk mengamati aktivitas guru dan aktivitas siswa selama pembelajaran berlangsung.Pada siklus I penelitian dilaksanakan $2 \mathrm{x}$ pertemuan.Berdasarkan hasil pengamatan yang dilakukan oleh pengamat terhadap pelaksanaan pembelajaran pada siklus I pertemuan I, persentase aktivitas guru adalah $65 \%$ dan persentase aktivitas siswa adalah 65\%. Pada siklus I pertemuan II, persentase skor rata-rata aktivitas guru adalah $67 \%$ dan persentase skor rata-rata aktivitas siswa adalah $67 \%$.

\section{Refleksi}

Berdasarkan hasil observasi dan hasil tes yang dilakukan, dapat disimpulkan bahwa hasil belajar belum mencapai kategori keberhasilan yang diharapkan dan kriteria ketuntasan yang ditetapkan. Dengan demikian peningkatan hasil belajar PKn akan peneliti lanjutkan pada siklus II dengan lebih baik sesuai rancangan pelaksanaan pembelajaran dengan model pembelajaran berbasis masalah yang disusun

\section{Siklus II}




\section{Kukuh Vandriani}

Hasil penelitian pada siklus kedua terdiri dari proses pelaksanaan model pembelajaran Kooperatif tipeTPS dan aktivitas siswa selama proses pembelajaran berlangsung sesuai dengan komponen yang tersedia pada lembaran observasi dan hasil tes belajar siswa yang dilaksanakan dalam pertemuan. Penelitian dilaksanakan sebanyak 2 x pertemuan yaitu pada hari Jum'at tanggal 1 April 2016 dan hari Jum'at tanggal 8 April 2016.

\section{Perencanaan}

Perencanaan pembelajaran disusun dan dikembangkan berdasarkan Kurikulum Tingkat Satuan Pendidikan (KTSP) mata pelajaran PKn kelas IV semester II. Menyusun RPP yang meliputi: standar kompetensi, kompetensi dasar, indikator, menetapkan materi pembelajaran, menyusun kegiatan pembelajaran, menetapkan media, sumber belajar dan penilaian. Adapun standar kompetensi dalam penelitian ini adalah 3.Menunjukkan sikap terhadap globalisasi di lingkungannya.KD 4.1 Menyebutkan contoh sederhana pengaruh globalisasi di lingkungannya.Dengan model kooperatif tipe TPS.S

Penilaian terhadap RPP dilaksanakan melalui lembar penilaian RPP dengan aspek penilaian yang terdiri dari: (a) kejelasan perumusan tujuan pembelajaran, (b) pemilihan materi ajar, (c) pengorganisasian materi ajar, (d) pemilihan sumber/media pembelajaran, (e) Kejelasan proses pembelajaran,(f) teknik pembelajaran, (g) format Penilaian.

\section{Pelaksanaan}

Pelaksanaan pada siklus II penelitian ini disesuaikan dengan dengan langkah-langkah yang dikembangkan Menurut Trianto (2012 :81-82) (1) thinking ( berfikir ) guru mengajukan suatu pertanyaan atau masalah yang dikaitkan dengan pelajaran, dan meminta siswa menggunakan waktu beberapa menit untuk berfikir sendiri jawaban atau masalah,siswa membutuhkan penjelasan bahwa berbicara atau mengajarkan bukan bagian berfikir, (2) pairing ( berpasangan) selanjutnya guru meminta siswa untuk berpasangan dan mendiskusikan apa yang telah mereka peroleh,interaksi selama waktu yang disediakan dapat menyatukan jawaban jika suatu pertanyaan yang diajukan atau menyatukan gagasan apabila suatu masalah khusus yang diidentifikasi,secara normal guru member waktu tidak lebih dari 4-5 menit untuk berpasangan, (3) sharing(berbagi) pada langkah akhir ,guru meminta pasang-pasangan untuk berbagi dengan keseluruhan kelas yang telah mereka bicarakan ,hal ini Afektif untuk berkeliling ruangan dari pasangan ke pasangan dan melanjutkan sampai sekitar sebagian pasangan mendaptkan kesempatan untuk melaporkan.

Untuk melakukan observasi terhadap hasil belajar siswa, dilakukan melalui penilaian terhadap dua ranah, yaitu penilaian kognitif, afektif.

\section{Pengamatan}

Kegiatan pengamatan dilakukan oleh observer untuk mengamati aktivitas guru dan aktivitas siswa selama pembelajaran berlangsung.Pada siklus II penelitian dilaksanakan $2 \mathrm{x}$ 
pertemuan. Berdasarkan hasil pengamatan yang dilakukan oleh pengamat terhadap pelaksanaan pembelajaran pada siklus II pertemuan I, persentase aktivitas guru adalah $77 \%$ siklus II peetemuan II 90\% dan persentase aktivitas siswa siklus II pertemuan I adalah $77 \%$ dan siklus II pertemuan II adalah 90\%.

\section{Refleksi}

Berdasarkan hasil observasi dan hasil tes yang dilakukan, dapat disimpulkan bahwa hasil belajar sudah mencapai kategori keberhasilan yang diharapkan dan kriteria ketuntasan yang ditetapkan. Dengan demikian peningkatan hasil belajar IPS dengan model pembelajaran Kooperatif tipe TPS sudah berhasil.

\section{PEMBAHASAN}

\section{Siklus I}

Hasil yang dicapai pada siklus I baik itu dari pelaksanaan maupun aktivitas guru dan siswa serta hasil tes belum maksimal seperti yang diharapkan, masih banyak siswa yang belum memahaminya dengan baik sehingga masih ada beberapa orang siswa yang belum tuntas. Peneliti berkeinginan siswa lebih aktif dan tertarik, lebih banyak bertanya, dan dapat menjawab pertanyaan guru dengan baik. Di dalam perencanaan guru harus mampu merancang RPP dengan memperhatikan kegiatan yang akan dicapai dan melaksanakannya dengan baik sehingga tercapailah tujuan pembelajaran yang diharapkan sebelumnya. Jadi, dalam perencanaan ini berisi rangkaian kegiatan yang harus dilaksanakan dengan baik agar tercapainya tujuan pembelajaran yang diharapkan.

Pelaksanaan penelitian tindakan kelas pada pembelajaran PKn ini merujuk pada model pembelajaran Kooperatif TPS yang dikemukakan Trianto (2012:81-82) “1)thinking (berfikir ), 2) pairing ( berpasagan ), 3) shering ( berbagi ).

Dilihat dari hasil belajar yang diperoleh siswa baik kognitif, afektif, nilai yang diperoleh siswa masih dibawah ketuntasan belajar yang diinginkan. Dari analisis penelitian siklus I, hasil belajar yang diperoleh siswa dengan skor rata-rata yaitu 73,1 Sedangkan ketuntasan belajar adalah 75\%. Dengan demikian dapat disimpulkan pembelajaran PKn dengan menggunakan model pembelajaran Kooperatif tipe TPS pada siklus I ini belum berhasil. Berdasarkan paparan data hasil pengamatan siklus I, maka direncanakan untuk melakukan perbaikan pembelajaran pada siklus II.

\section{Siklus II}

Perencanaan pada siklus II mencapai keberhasilan dengan sangat baik. Penelitian pada siklus II dilaksanakan sesuai dengan tahap-tahappembelajaran Kooperatif tipe TPS yang dikemukakan Trianto (2012:81-82) “1)thinking (berfikir ), 2) pairing ( berpasagan ), 3) shering ( berbagi ). 


\section{Kukuh Vandriani}

Secara umum pada siklus II ini pembelajaran sudah berlangsung sesuai dengan yang diharapkan. Hal ini mengindikasikan bahwa pembelajaran PKn dengan model pembelajaran Kooperatif tipe TPS yang dilakukan sudah efektif, sebab sudah banyak siswa mampu berpikir aktif, kreatif dan inovatif dalam pembelajaran sehingga tujuan pembelajaran dan kompetensi yang diharapkan dapat dicapai.

Pembelajaran PKn menggunakan pembelajaran kooperatif tipe TPS pada siklus II ini sudah berjalan dengan baik, ini dapat dibuktikan dengannilai yang diperoleh siswa sudah meningkat yaitu Siklus II pertemuan I dengan rata-rata 81,8.Siklus II pertemuan II dengan rata-rata 92,7\% Ini terbukti dengan meningkatnya hasil belajar siswa dibandingkan pada siklus I.

Melalui PTK ini peneliti berhasil membuktikan bahwa penggunaan pembelajaran kooperatif tipe TPSdalam pembelajaran PKn dapat meningkatkan hasil belajar siswa, dapat mengembangkan kemampuan berpikir kritis, tanggap dan inovatif. Dengan demikian, penerapan model pembelajaran kooperatif tipe TPS dalam pembelajaran dapat membuat siswa aktif, tertarik dan termotivasi dalam kelompoknya untuk belajar.

\section{SIMPULAN DAN SARAN}

\section{SIMPULAN}

Simpulan yang dapat diambil dari penelitian ini adalah sebagai berikut:

1. Rencana pelaksanaan pembelajaran peningkatan hasil belajar siswa dengan menggunakan model pembelajaran kooperatif tipe TPS pada pembelajaran PKn ini dilakukan dengan baik, mulai dari kegiatan Think (berfikir). Pair ( berpasangan) dan Share ( berbagi). Sesuai dengan langkah-langkah pembelajaran model kooperatif tipe TPS. ini dapat dilihat dari siklus I pertemuan I tingkat keberhasilan 64\% (cukup) dan pada pertemuan II tingkat keberhasilannya adalah $67 \%$ ( cukup ),dan pada siklus II mengalami peningkatan dengan tingkat keberhasilan pada pertemuan pertama 75\% ( baik) dan pertemuan kedua $89 \%$ ( sangat baik).Dapat dilihat bahwa hasil pengamatan RPP mengalami peningkatan dari siklus I ke siklus II.

2. Pelaksanaan pembelajaran dengan model kooperatif tipe TPS, dilaksanakan sesuai dengan kerangka rancangan belajar TPS, yaitu : Think ( berfikir) dimana siswa diminta berfikir tentang topic materi atau permasalahan yang disampaikan guru secara individual. Pada tahap Pair (berpasangan) siswa berpasangan untuk mendiskusikan apa yang telah dipikirkan. Pada tahap Share (berbagi) siswa dan pasangannya berbagi ide dengan seluruh kelas tentang apa yang telah mereka diskusikan. Siswa mampu tampil di depan kelas secara bergiliran pasangan demi pasangan untuk membahas apa yang telah mereka diskusikan. Proses pembelajaran dengan model kooperatif tipe TPS, telah berhasil meningkatkan keaktifan siswa dalam pembelajaran, dan aspek siswa pada siklus I adalah 67\% dengan kualifikasi cukup, sedangkan pada siklus II adalah 90\% dengan kualifikasi sangat baik. 
3. Hasil belajar siswa denganmodel kooperatif tipe TPS dalam pembelajaran PKn Di Kelas IV SDN 10Bandar BuatKota Padang, dapat meningkatkan hasil belajar siswa. Hal ini dapat dilihat dari rekapitulasi penilaian hasil belajar siswa siklus II lebih tinggi jika dibandingkan dengan rekapitulasi hasil belajar siswa siklus I yaitu 73\%meningkat menjadi 87,2\% atau meningkat sekitar 14,2\%. Dan juga dapat dilihat pada ketuntasan hasil belajar siswa pada siklus II lebih tinggi jika dibandingkan dengan persentase ketuntasan hasil belajar siswa pada siklus I. Persentase ketuntasan pada siklus I adalah 38,8\% dengan kualifikasi kurang sedangkan pada siklus II 94,4\% dengan kualifikasi sangat baik. Dapat dilihat bahawa hasil belajar dan persentase ketuntasan belajar siswa mengalami peningkatan dari siklus I ke siklus II.

\section{Saran}

Berkenaan dengan hasil penelitian, peneliti mengemukakan beberapa saran yang sekiranya dapat memberikan masukan untuk dapat meningkatkan hasil belajar siswa, adapun saran yang peneliti kemukakan yaitu :

1. Perencanaan pembelajaran sebaiknya guru harus mempersiapkan sumber-sumber yang sesuai dengan materi lebih kurang 4 buku sehingga guru dapat merencanakan pembelajaran dengan baik. Guru juga harus memperhatikan soal-soal latihan yang diberikan agar sesuai dengan tujuan pembelajaran, sehingga proses pembelajaran berjalan secara optimal.

2. Pelaksanaan pembelajaran dengan menggunakan model kooperatif tipe TPS, sebaiknya guru harus mampu menguasai manajemen kelas sehingga suasana kelas lebih menyenangkan .

3. Hasil belajar sebaiknya memperhatikan penilaian aspek kognitif, afektif. Hal ini dikarenakan dalam menilai siswa harus sesuai dengan materi yang diberikan selama pembelajaran berlangsung.

\section{DAFTAR PUSTAKA}

Aderuslina. 2007. Konsep Dasar Evaluasi Hasil Belajar. (online) http://aderuslina.wordpress.com. (diakses tanggal 25 november 2015).

Ahmad Susanto. 2013. Teori Belajar Dan Pembelajaran Di Sekolah Dasar. Jakarta: Kencana Prenada Media Group.

Anita Lie.2008.Cooperative Learning.Jakarta : PT Grasindo. Asep Jihad, dkk. 2008. Evaluasi Pembelajaran. Jakarta: Multi Pressindo.

Aziz Wahab , Dkk. 2002. Pendidikan Pancasila Dan Kewarganegaraan (Ppkn). Jakarta: Universitas Terbuka.

Basrowi, Dkk. 2008. Memahami penelitian kualitatif. Jakarta : PT Rineke Cipta.

Buchari Alma.2009.Guru Profesional.Bandung: Alfabeta .

Cepy Riyana.2011. Kurikulum Dan Pembelajaran. Jakarta: PT Raya Grafindo.

Depdiknas. 2006. Kurikulum Tingkat Satuan Pendidikan. Jakarta: Depdiknas.

Hamzah B. Uno, dkk. 2011. Menjadi Peneliti PTK Yang Profesional. Jakarta: PT Bumi Aksara.

Isjoni.2013.Pembelajaran Kooperatif.Yogyakarta:Pustaka Belajar.

Istarani.2012. 58 Model Pemnelajaran Inovatif. Medan: Media Persada. 
Kunandar. 2010. Langkah Mudah Penbelitian Tindakan Kelas Sebaagi Pengembangan Profesi Guru. Jakarta: PT Raja Grafinndo.

Kunandar. 2011. Implementasi Kurikulum Tingkat Satuan Pendidikan (KTSP) dan sukses dalam sertifikasi guru. Jakarta: PT Raja Grafindo Persada.

Miftahul Huda.2011.Cooperative Learning.Yogyakarta:Pustaka Belajar.

Mulyana .2010.Kurikulum Tingkat Satuan Pendidikan. Bandung : PT Remaja Rosdakarya

Nana Sudjana . 2009. Penilaian Hasil Proses Belajar Mengajar. Bandung: PT Remaja Rosdakarya.

Nanang Martono. 2011. Metode Penelitian Kuantitatif. Jakarta: PT Raja Grafindo Persada.

Ngalim Purwanto.2006.Prinsip-Prinsip Dn Teknik Evaluasi Pengajaran. Bandung : PT Remaja Rosdakarya.

Nur Asma.2008.Model Pembelajaran Kooperatif.Padang: UNP Pres.

Rusman.2012.Model-Model Pembelajara.Bandung:PT Raja Grafinda Persada.

Suharsimi Arikunto dkk. 2007. Penelitiamn tindakan kelas . Jakarta:Bumi aksara.

Trianto.2012.Mendesein Model Pembelajaran Inovatif-Progresif. Jakarta : Kencana Prenada.

Wina Sanjaya .2012.Penelitian Tindakan Kelas. Jakarta : Kencana Prenada.

Zainal Aqib.2013.Model Media dan Strategi Pembelajarn Konsekstual(Inovatif). Bandung: Yrama

Widya . 